\title{
Jenny Bergenmar*
}

\section{The North seen from the South in the Spanish reception of Selma Lagerlöf}

https://doi.org/10.1515/ejss-2018-0015

\begin{abstract}
When Selma Lagerlöf became a Nobel laureate in 1909, her works were translated into new languages and introduced to countries, including Spain, where she had previously been unknown. This article traces the image of Sweden and Scandinavia reflected in Selma Lagerlöf's reception in Spanish newspapers and periodicals around 1910. The idea of a distinctive Nordic or Scandinavian identity is discernible in the critics' characterizations of Lagerlöf's works; however, there is tension between their presentations of Lagerlöf as a representative of the region of Scandinavia or the North in general versus just one nation (Sweden) or province (Värmland). Building on research in imagology and literary transfer, this article investigates how and which regional, national, and provincial identities, geographies, and stereotypes of North and South were activated in support of a particular idea of the author.
\end{abstract}

\section{Introduction}

Studies of literary exchange usually focus on cultural centres or on relations between peripheral literatures and centres. The purpose of this article is to contribute to a better understanding of the transnational dimensions of literary history by studying the relation between two (semi-)peripheral European locations, Sweden and Spain. The reception of Selma Lagerlöf in Spain lends itself well to this purpose: as a Nobel laureate, she was introduced in Spain as a figure of interest and importance in the European literary sphere. Still, she was perceived as rooted in her home, thereby bringing contrasts between the North and the South into play. Spain and Scandinavia had in common that both areas were located outside of the political and cultural centres of Britain, France and Germany. Though Scandinavian and Spanish literature were not as marginalized as, for example, the literatures of the smaller languages of Eastern Europe, it remained

\footnotetext{
*Corresponding author: Jenny Bergenmar, University of Gothenburg, Department of Literature, History of Ideas and Religion, Box 200, SE-405 30 Göteborg, Sweden, e-mail: jenny.bergenmar@lir.gu.se
} 
semi-peripheral, according to Theo D'Haen (D'Haen, 2012, 153). One important difference between Scandinavia and Spain was however, that by the turn of the century Spain was associated with the past and the North with the future, as exemplified by the image of the progressive women of the North. In the 1890s the Spanish press introduced the Nordic woman as a symbol of modernity and progress through Ibsen's Nora (Lindholm Narváez 2013, 201-202).

This article begins with one example from the 1920s, but the focus will mainly be on the period 1909-1911, since Lagerlöf was introduced to a Spanish audience when she was awarded her Nobel Prize in 1909. Based on previous research in imagology and literary transfer, examples of different conceptualizations of the North in travelogues and in texts about Lagerlöf in the Spanish press before 1909 are provided, and in addition to this, a more extended analysis of how these ideas recur in the reception of Lagerlöf in Spain is proposed. The main questions posed to this material are "How are regional, national, and provincial identities used to support a particular idea of Lagerlöf as an author?” and "What literary contexts, geographies, and stereotypes - particularly, ideas of the North and the South - are activated in Lagerlöf's reception in Spain? By regional I refer to notions about Scandinavia and the North, by national to the construction of Sweden as a nation, and by provincial to ideas about the rural provinces represented in Lagerlöf's texts, mainly Värmland and Dalarna.

\section{A dedication to Selma Lagerlöf}

The Swedish edition of Concha Espina's (1865-1955) 1920 novel, El Metal de los Muertos, included a preface by Anders Österling (a member of the Swedish Academy) and a dedication to Selma Lagerlöf. Espina was seven years younger than Lagerlöf and already an established author in Spain, known for her sentimental novels in which female protagonists defend the rights of women. El Metal de los Muertos, however, is a novel criticising the conditions of miners in the Asturian region of northern Spain (Ugarte 1997, 99-100). In the dedication, Espina writes that she dares to dedicate the Swedish translation to Lagerlöf because she is convinced that it will be received cordially and that Lagerlöf's name, inscribed in European literature, will be joined with that of a foreigner from the ancient Castilian soil (Espina 1925, 3). That Lagerlöf read the dedication is evident in a printed statement, published in the multilingual promotional publication, L'Oeuvre de Concha Espina a l'étranger (1925). Most likely it was reproduced from a letter to Espina and in that case Lagerlöf may not have been asked for permission to be 
cited. The statement is a polite and generous acknowledgement of Espina's talent. Lagerlöf thanks Espina for the books she has sent her, and she praises Espina's ability to express Spain's customs and spirit and to introduce the reader to a Spain beyond that of the travelogues (L'Evre de Concha Espina a l'étranger, 80). Espina cleverly creates a relation between herself and the distinguished Swedish writer by uniting her name with Lagerlöf's in the dedication and enticing Lagerlöf to respond and further strengthen the connection. This exchange must no doubt be understood in terms of strategy as Espina was a recurring nominee for the Nobel Prize. $^{1}$

Espina most likely read and appreciated Lagerlöf, but she might also have felt her, as its only woman, to be an approachable member of the Swedish Academy. There were also aesthetic affinities between the women, highlighted in Espina's dedication and Lagerlöf's response. Espina and Lagerlöf both depicted the customs and spirit of their nations, and Espina's connection to the Castilian soil was similar to the connection Lagerlöf was said to have to her own land when presented abroad - particularly, but not only, in Germany. The ideological contexts of Lagerlöf's international reception needs further exploration: conservatives, nationalists, and in some case fascists and Nazis were avid readers of Lagerlöf. AnnSofi Ljung Svensson and Jennifer Watson have studied this in the German context (Ljung Svensson 2011; Watson 2014). However, it is an important aspect of her reception in France as well, her translator and introducer André Bellessort being a member of the conservative and nationalist Action Française, and possibly also in Spain, with at least the one example of Espina's admiration. Even if much of Espina's work preceded her commitment to fascism, according to Ugarte "there has always been a trace of the ultraconservative adherence to tradition, spirit, and nationhood" in her texts (Ugarte 1997, 111). Although outside of the chronological scope of this article, the exchange between the two authors points to the connection between ideas of tradition, nationality, and political ideology. Aspects of the exchange also surface in Lagerlöf's early reception in Spain: emphasis on nationhood, connectedness with the native home, and the woman as author. Interestingly, Espina does not construct the relation between herself and Lagerlöf as a relation between North and South, but rather as a meeting between the regional ("the old Castilian soil") and "European letters".2

\footnotetext{
1 According to the Nobel Prize Nomination Database, Espina was nominated 25 times, both nationally and internationally. "Nomination Database”, Nobel Media AB 2014. Web. 26 May 2017, http://www.nobelprize.org/nomination/archive/show_people.php?id=2838

2 "la vieja tierra de Castillia", "las Letras europeas". My translation.
} 


\section{The North and the South}

Ideas about the contrast between people of the North and people of the South have a long history. From Montesquieu on, northern peoples have been described as cooler, more introspective and individualistic, and better suited to democracy and egalitarianism that the peoples of the South, who are thought to be more sensual, collective, and polished, but less trustworthy and better suited to hierarchy and aristocracy (Leersen 2000, 271). These ideas provide a necessary context to cultural exchanges between Scandinavia and Spain. German and British perspectives clearly predominate in critical analyses of the cultural stereotypes of Sweden and Scandinavia (see for example Gentikow 1978, Fjågesund/Symes 2003), but Vincent Fournier's investigation of French essayists and travellers' images of Sweden and Norway (Fournier 1989) is the most relevant to this article. Studies investigating the image of Scandinavia in Southern Europe are less common, and rarer still for Spain, as Scandinavians travelling south tended more often to go to Italy. However, the historian Peter Stadius, in his dissertation, investigated the image of the North presented in Spain around 1900 through travelogues. At that time, there was a surge of interest in the Nordic countries among intellectuals and scientists in Spain (Narváez 2015, 183). Stadius distinguishes three different attitudes to the North: (1) the traditionalist image of the North contrasted critically to southern Europe as peripheral, underdeveloped, barbaric, and foreign; (2) the progressive image of the North as a modern Utopia of technology and societal reforms such as in education; and (3) the pan-Latinist view, opposing the idea of Arian racial superiority offered by scientists in the late 19th century. This latter view was not programmatically founded in the pan-Latinist movement, but was based on similar ideas of the Latin world and culture as the cradle of European civilization (Stadius 2005, 92, 97). In contrast to the traditionalist image, this discourse (like the progressive) could be critical of the contemporary societal conditions in Spain, but contrary to the progressive discourse, it rejected Scandinavia as a model for development.

Stadius includes only male travellers in his investigation; however, one of the most renowned female authors and feminists of Spanish fin de siècle literature, Carmen de Burgos, also travelled in and wrote about the North. Elena Lindholm Narváez distinguishes two contrasting preconceptions of the North in the literary circles to which de Burgos belonged: one is a utopian model of progress and modernity, the other an ideal of romantic exoticism manifested in the popular stories of Vikings and Wagner's operas (Lindholm Narváez 2015, 189). The first coincides with Stadius' second point; elements of the second may be found in all three: the Viking as a personification of the barbaric (1), the Valkyrie as prede- 
cessor of the independent, modern woman of Scandinavia (2), and the Old Norse heritage as proof of the Germanic culture as essentially different from the Latin, a country inhabited by uncultivated heretics (3).

The view of Scandinavia as a model for progress and modernity was partly an effect of the "modern breakthrough", and the question of women's emancipation attracted attention through modern Scandinavian drama, in particular Ibsen's A Dolls's House, especially in modernist Catalonia (Lindholm Narváez 2013, 202-205; Siguan 2001, 31-37). De Burgos mentions several notable Swedish women, among them Lagerlöf, who is described as a national-romantic author. She regrets not having the opportunity to meet Lagerlöf, who was in Italy at the time of de Burgos's stay in Stockholm. Will the Italian sun fertilize the imagination of the North? de Burgos asks (de Burgos, 1915, 165). Implicit in her phrasing is that Northern authors need the South for inspiration. De Burgos connects Lagerlöf both to romantic exoticism and to modernity, presenting her not as a modern author and feminist in the same sense as Ellen Key, whom de Burgos describes as the country's most vigorous intellectual mind, but as a modern, independent woman, who could travel to Italy in search of inspiration for her next book. Travelogues generally aim to present and introduce a place through a factual report of the author's own journey (Youngs 2013, 5). De Burgos travelogue shows that these facts are readily combined with fantasy, in this case ideas about the dynamics and complementarity of the North and the South. As Lindholm Narváez has pointed out, de Burgos travel to the North, which took her as far as the North Cape, was in itself a transgression of the norms of femininity and can be viewed as part of her continued search for modern femininity (Lindholm Narváez 2015, 184-185). Evidently, authors such as Key and Lagerlöf were of interest in this pursuit, as well as other aspects of the emancipated Nordic woman.

\section{Reception before the Nobel Prize 1909}

By the time de Burgos travelled to Sweden in 1914, Selma Lagerlöf was known to those of the Spanish public who followed the news. Her status as Nobel Prize laureate in 1909 broadened her recognition from intellectuals and those interested in European literature to a wider public sphere, since it was reported in regular newspapers. However, there were a few references to Lagerlöf in the Spanish press before 1909. The first I have been able to detect, with the help of the Hemeroteca digital, the digital library of Biblioteca Nacional de España (BNE), is in a travelogue from Scandinavia published in the journal España 1898 under the headline "A Mining Excursion to the Scandinavian Peninsula. From Bilbao 
to Gellivara". ${ }^{3}$ Since the article's aim is to give an overview of the nature, society, and history of the peninsula, it also includes literature, but superficially, merely though name-dropping. The writer, an engineer and industrialist named Julio de Lazúrtegui, first mentions the contemporary male authors Heidenstam, Snoilsky, "Livertin, Wennerbeg, Strinberg” [sic] and then the noteworthy female writers "Fredrika Bremer, Emilia Flygare Karlén, Selma Lagerlöf, Matilde Malling y Elena Key" [sic] (de Lazúrtegui 1898, 3). He stresses how the darkness and cold of the winter produces a robust and agile people, with the capacity to endure hard times. As in many other travelogues, Swedish nature is celebrated: its pure air and serene sky. Stadius emphasises that as a keen supporter of modernity and technological progress, de Lazúrtegui describes Sweden as exemplary in its industrial development (Stadius 2005, 138), and like de Burgos later, he focuses on the modernity and possibilities of Sweden, although de Burgos is more interested in women's emancipation and de Lazúrtegui in technological progress. Discussing Arctic expeditions, Peter Fjågesund points out that in the last decades of the nineteenth century "the North contained a fundamental ambiguity: it became, on the one hand, an arena in which spearhead technology was employed to subjugate the forces of nature; on the other, it became an admired image of Nature in its purest and most majestic forms" (Fjågesund 2014, 444). This ambiguity can be observed in the simultaneous focus on technological development and admiration of Nordic nature in de Lazúrtegui's writing, for example when he combines the praise of the efficiency of the Swedish railways with a description of the astounding view of the landscape he experienced on his journey by train from Malmö to Gällivare (Stadius 2005, 195).

The next references to Lagerlöf in the press before 1909 occur in summaries or perhaps direct translations of articles in the French press. She is mentioned by the Nuestro tiempo section "Revista de las revistas", a review of foreign intellectual debates and cultural events, in their announcement of the death of Oscar Levertin in 1906: "Levertin had a great importance in Sweden, where his death will be keenly felt since he was one of the three authors - Heidenstam and Selma Lagerlöf are the two others - who understood that their country did not always have to be inspired by the foreign" (Anonymous 1906, 542). ${ }^{4}$ Lagerlöf is here singled out as one of three specifically national authors renewing Swedish literature

3 "Una excursión minera a la península escandinava. De Bilbao a Gellivara".

4 "Levertin tuvo una gran importancia en Suecia, donde su muerte ha de ser muy sentida, pues fué uno de los tres escritores contemporáneos suecos - Heidenstam y Selma Lagërlof [sic] los otros dos - que comprendió que su país no debía inspirarse siempre en el extranjero." My translation. All further translations from press and periodicals are in my translations, with the original in footnotes. 
without reference to foreign writing. In 1907, an article on mysticism in Scandinavian literature was republished in La Lectura (like the report of Levertin's death) from the French La Revue. In it, Martine Remusat investigated a turn to Christian mysticism and Catholicism, as well as a fascination for the historical, particularly the medieval period, in Scandinavian literature. Lagerlöf is quoted in this context: "No one can suppress the pain, but much will be forgiven to those who help others to overcome" (Remusat 1907, 343). ${ }^{5}$ In this article, it is certainly not the progressive modernity of Scandinavia that is being conveyed, but an introspective and nostalgic sensibility with clear associations to Catholicism. Remusat mistakenly states that Strindberg converted to Catholicism before writing Inferno, Legends, and To Damascus (Remusat 1907, 341). These are the only references to Lagerlöf in the Spanish press before 1909 I have found in the BNE Hemeroteca digital record, other than announcements of translations of her texts to French. ${ }^{6}$

These examples give an impression of Lagerlöf's presence (or absence) in the Spanish literary field before 1909. A search in the Hemeroteca digital record reveals that Heidenstam is mentioned somewhat more often during the same period. Ellen Key is mentioned considerably more, especially in connection to her book The Century of the Child and her ideas about pedagogy. After the announcement of the Nobel Prize the situation changes, but judging from the sources included in Hemeroteca, there are still not that many articles about Lagerlöf. The first announcements of the Nobel Laureates normally contained only a very brief introduction. In La illustración artística the reader is informed that Lagerlöf was born in 1858 on Mårbacka, that she was educated at home until she was admitted to the Royal Advanced Teacher's Seminary in Stockholm at the age of 24, and that she was the head of an elementary school in Landskrona from 1885-1895. The report goes on to say that in 1890, she became famous as a writer after having won the first prize in a competition in Idun, a feminist journal, and after that she wrote many novels and tales (translated into several languages), had travelled extensively in the previous 15 years, and had used impressions from these travels in her novels Jerusalem and The Miracles of Anti-Christ. This account is both familiar and unfamiliar. The facts are not exactly but approximately correct (she was

5 "Nadie puede suprimir el dolor, pero mucho les será perdonado á quienes ayuden á los demás á sobrellevarlo.”

6 Quantifications are very unsure, since the quality of the scanned newspapers and journals differs. Optical character recognition (OCR) makes the material searchable, but in many cases the quality is bad and characters are misinterpreted. Another source of error is that names of Swedish authors were frequently misspelled. Lagerlöf is usually spelled "Lagerlof" or "Lagerloef”. See Rideout for a methodological discussion about using the BNE Hemeroteca digital record (Rideout 2016, 19-21). 
not the head of the school in Landskrona and Idun was not a feminist journal). Lagerlöf is, as in her Swedish reception, connected to Mårbacka and presented as a teacher. But she is also presented as a modern woman, independent, widely travelled, and self-supporting. In this description, she emerges as a feminist, read in many languages, and a "new woman" in much the same sense as Carmen de Burgos. However, in this case, she is not connected to the North or to any specific national traits. Instead, the fact that she is a woman is singled out as the most important aspect (Anonymous, La Illustración Artística 1909, 847).

\section{Northern landscapes}

In the beginning of 1910 more detailed introductions of the author began to appear. The texts often contain critical judgements and journalistic introductions recycled from previous publications. It is all too easy to recognize shared opinions of Lagerlöf in the Swedish critical reception, which tended to “tie Lagerlöf's literary activity to her home region of rural Värmland in western Sweden, and to remove artistic agency from the author by constructing her as the voice of a tradition of oral storytelling, as a mouthpiece for the Swedish soil itself, or as an embodiment of moral values" (Thorup Thomsen 2014, 13). The same focus on Lagerlöf as an inheritor of an oral treasury of tales retold in her books is recurrent, as is her association with the rural and the provincial. In this context, conceptions about the North are also reflected on various levels. Selma Lagerlöf has "a love of the soil", and she writes about the "spirit of the people" (Por Esos Mundos 1910, 29). ${ }^{7}$ The same article speaks of Lagerlöf's anthropomorphism and makes her a spokesperson for the people, the animals, the forests, the sea, and the clouds. What then characterizes this landscape? When discussing The Wonderful Adventures of Nils Holgersson, a narrative which gives examples of different landscapes and seasons, it is still the freezing latitudes of the North, the cold mystery of the snow, and "the fierce instincts of the ferocious beasts" that are emphasized. ${ }^{8}$

The North is, not surprisingly, constructed as an antithesis to the South and this is most visibly expressed in the connection critics establish between Lagerlöf and a specific Northern landscape and climate. The critic Ángel Guerra, writes that to understand Lagerlöf, or writers in general, it is necessary to apply Taine's idea of "la race, le milieu et le moment", although he focuses primarily on race and

7 "un amor de tierra”, “el alma de los paisajes”.

8 "las heladas latitudes de Nordland", "el frío misterio de la niebla", "los torvos instintos de las bestias feroces". 
milieu. ${ }^{9}$ In an article from 1911 introducing Lagerlöf to Spanish readers, he uses French images of the North from travelogues and literary criticism to describe the character of Sweden and its people. He quotes the writers Jacques de Coussange (pseudonym for Barbe de Quirielle) and Jane Michaux, who both wrote about Swedish literature and mentality. De Coussange repeats the romantic stereotypes of the snow illuminating the long nights of winter and the restlessness of the bright nights of summer. Michaux has a less romantic and more negative take: the landscape does not invite happiness in her view; it is sombre and melancholic, and contributes to withdrawal and rumination in Swedes, and even to suicide (Guerra 1911, 123). The climate is also presented as the basis of a Scandinavian love of the tragic and the heroic. Apart from Ángel Guerra, who wrote two longer articles about Lagerlöf in 1910 and 1911, only one other critic introduced Lagerlöf more thoroughly and knowledgeable. In his article "El triumfo de la imaginación" (1910), Julian Juderias contrasts Lagerlöf's writing with the naturalist psychological case study and finds she represents a triumph of the imagination. This is not surprising, he argues, since Sweden is a poetic country, with its blue lakes and centennial pines, its darkness in winter and bright nights that seem like days. He cites André Bellessort, Lagerlöf's French translator and introducer, and writes that Swedes demand that their authors tell fantastic and entertaining stories to help them endure the monotony of the winters and the sleeplessness of the summers (Juderias 1910, p. 44). The aesthetic of Swedish literature is thus connected not only to geography and topography, but perhaps more importantly for Spanish critics, to climate. For Taine, also a major inspiration to Bellessort (Fournier 1989, 76), the climatological aspect of "le milieu" was central (Leersen 2007, 19), and this seems to be reflected in both Guerra's and Juderias's texts.

\section{The people of the North}

The idea of the essential difference between the North and the South is connected not only to nature, but also to people. When Lagerlöf is presented in the progressive cultural journal La España moderna in 1910, the writer explicitly refers to André Bellessort - yet another example of critical recycling. In line with Bellessort's view, Lagerlöf is understood as an author in contact with "the people". To understand her work, one must understand the nature of the Swedish people (Anonymous, 1910, p. 200-201). This idea characterizes her reception in general,

9 Ángel Guerra was a pseudonym taken from the novel Ángel Guerra by Benito Pérez Galdos. His real name was José Betancourt Cabrera. Rogers/Lapuente 1989, 217. 
as representative of " $[\mathrm{t}]$ he whole soul of a nation and a race, with its deepest roots in the native land, hard and permanent in its unmistakable spiritual character through time" (Ângel Guerra presenting Lagerlöf in the series "Las Escritoras modernas" 1910, 91). ${ }^{10}$ Through the old stories of her native home, Lagerlöf gives voice to the atavistic spirit of her country. Embedded in Guerra's description is both the idea that Lagerlöf is retelling the tales she inherited from an oral tradition, and the idea that Lagerlöf, like her country, is beyond modernity, representing something authentic and traditional. Guerra clearly employs both a widespread idea about the authenticity of the North (Stadius 2005, 53-55), and an understanding of culture based on racial differences, possibly connected to the pan-Latinist distinction between Latin and Germanic identified by Stadius as an aspect of the Spanish conception of the North (Stadius 2005, 93). In his description of Lagerlöf, Guerra reiterates the now established tropes present in the Swedish, German, and French receptions. He repeatedly situates Lagerlöf in a specific geographic and cultural domain: her "native region", "birthplace", or "native soil"."11 These expressions also recur in other articles, for example in La Ilustración artística 1914, where the she is again placed in her "birthplace", "rooted in it, like a centennial tree" (406). ${ }^{12}$ In Guerra's opinion, a consequence of the deep connection between Lagerlöf's work and her origins is that Selma Lagerlöf will never be a great author in universal literature. Instead, she has the amiable effect of a grandmother telling fantastic stories during the long winter nights (Guerra 1910, 92). She is not to be read for her learnedness or aesthetic techniques, but for the force and charm of her innocent spirit (Guerra 1910, 91). In Guerra's portrayal this description seems to be valid for both the author and her origins: Lagerlöf is a national author, but to truly be a national author, you must be anchored in your native soil. The provincial, then, epitomizes the national, and the discourse of an inherited literary tradition is implicitly connected to a biological inheritance (race).

In the longer article on Lagerlöf published by Guerra 1911 in the same journal, he develops the same themes. He returns to the myth that Lagerlöf retells the stories of her childhood, but connects the superstitious and supernatural elements not only to this inherited trove of tales, but to the Scandinavian race (Guerra 1911, 118). He admires Gösta Berling’s Saga, but it remains foreign to him. To fully understand it, he asserts you must be born Scandinavian, not Latino (Guerra 1911, 131).

10 ”Toda el alma de una nación y de una raza, con sus más hondas raíces en la tierra nativa, dura y permanente en su inconfundible cuño espiritual a través del tiempo".

11 “terruño natal”, "rincón nativo", "tierra nativa”.

12 "Selma Lagerlof ha vivido siempre en el rincón nativo, arraigada en él como un árbol centenario." 
In contrast to the 1910 article, Guerra now states that Lagerlöf, despite her genuine "Swedishness", is a part of universal literature (Guerra 1911, 137). Juderias, for his part, cites a "German critic", contending that Lagerlöf's timelessness and rootedness in her people proves that despite changing times and societal transformations, people continue to have the same national character (Juderias 1910, 46). Not surprisingly, there are several references to the French critical reception of Lagerlöf, but also a couple of references to the German. Apart from Juderias, an article in Alrededor del Mundo 1913 quotes a German critic naming Lagerlöf "the greatest authoress of our times" (165).

The discourse on literature in relation to race and origin is, as previously mentioned, partly a product of Taine's theory of literature. However, it was (as in Taine's theory) also part of the scientific discourse on racial differences flourishing during this period. Although the German critics read Lagerlöf as a Germanic author, writing the same kind of Heimat literature written in Germany (Ljung Svensson 2011), and French critics sometimes described her as Germanic (Bergenmar 2017), Spanish critics specifically discuss the Scandinavian race and the Scandinavian region. Why she is described as Scandinavian rather than Germanic is not easy to answer. One possible explanation might be that Sweden and the Scandinavian region differed from Germany in the sense of being on the fringes of Europe, whereas Germany was central and culturally influential. Perhaps this can be read as a response to what Walter Mignolo called the "imperial difference”, placing Germany alongside France and England at the heart of Europe (Mignolo 2002). When the critics identify Lagerlöf as Scandinavian rather than German/Germanic, it could be a way of separating her from Germany as a culturally central nation, placing her on the periphery, and thereby positioning her on the same level as Spanish authors in the European literary field. It could also be a consequence of Spanish interest in Scandinavian literature in the wake of the modern breakthrough.

\section{Authentic past and progressive future}

Contrary to the image of the modern Scandinavian Utopia emphasized by de Lazúrtegui and de Burgos, Lagerlöf's literature is not primarily associated with modern and progressive ideas, but with a return to tradition and with an antimodern aesthetic movement, although this tendency is not clear-cut. Juderias situates Lagerlöf in the modern literary world and writes that she represents a "triumph of imagination" (Juderias 1910, 44), something completely divergent from the determinism and meticulous depiction of reality in naturalism. In the 
previously mentioned article in Alrededor del Mundo 1913, Lagerlöf is said outright to have founded a new aesthetic programme. Instead of joining the strong realistic current in European literature at the time she adopted a new method: she wrote about the vices and vulnerabilities of men as something grand and beautiful (Alrededor del Mundo 1913, 9). Moreover, in descriptions of Lagerlöf herself the progressive and the regressive are often combined. The article in Alrededor del Mundo 1913 begins with the sensational fact that the best Swedish author is a woman. This is a novelty, and precisely as new as her aesthetics. But when the writer continues to describe her, her independence and ambitions are scaled down: "Selma Lagerlöf is a woman without ambitions, modest, simple, who lives a quiet life and does not wish to be a celebrity", the article continues (Anonymous, 1913 , 9). ${ }^{13}$ This image of the author is sometimes also reflected in the photographs printed in the press. When the Nobel Prize winners were presented in the journal La Hormiga de Oro in January 1910, the male laureates have official portraits, while Lagerlöf is presented by a photograph of herself and her mother, sitting in the garden outside a house, probably her home in Falun. This is in line with the characterization of the author as a modest, simple woman, and with the image of an amiable grandmother, put forward by Guerra.

Juderias, however, is more inclined to see her as a modern woman. Both Key and Lagerlöf, writes Juderias, are authors who leave a lasting impression on literature, but are also conspicuous representatives of the feminist advance towards a more prominent place for women in society. For those worried that emancipation could cause disruption, Juderias argues that Key and Lagerlöf are proof that women can and should occupy the place to which they aspire, and that these ambitions do not deprive them of any of the attractions, charms, and virtues of their sex (Juderias 1910, 43). This modern aspect of Lagerlöf's author persona is also stressed in an article from 1914 in La Esfera, in which her appointment as a member of the Swedish Academy and the French scholar Leontine Zanta's doctoral degree at Sorbonne are hailed as "two feminist victories" (7). The article focuses on the patriarchal societal conditions surrounding these achievements: Lagerlöf was the first woman to be appointed a member of the Swedish Academy (not yet possible in the Spanish Academy, Academia de la Lengua, or in the French Academy), and Zanta defended her thesis in front of a room filled with the most eminent men in Paris. Sweden is presented as a positive example by admitting women to high positions in cultural and academic life, and Lagerlöf is seen as a pioneer in the progressive country of Sweden.

13 "Selma Lagerlof es una mujer sin ambiciones, modesta, sencilla, que vive una vida retirada y no aspira a la celebridad.” 
In the same article, however, the discourse on Lagerlöf's connection to an authentic past is also present. She is not mentioned in any modern literary context, but instead is said to continue a tradition from Homer and Virgil. She captures "the soul of Sweden", inherited from rough Vikings and berserks, and she serves, glorifies, and educates the Swedish people. ${ }^{14}$ This article clearly shows the existing images of a modern Sweden with Lagerlöf as a pioneering Swedish woman author, and the traditionalist image of Sweden as foreign and primitive and Lagerlöf as an interpreter of this culture. To return to the three different attitudes to the North distinguished by Stadius - the traditionalist, the progressive, and the pan-Latinist - the first two are clearly present in this text, but the pan-Latinist is not. Despite being the heiress of Vikings, Lagerlöf's literature is connected to the classical heritage of Virgil and Homer, with no clear line drawn between Germanic and Latin. Whether a progressive or traditionalist aspect of Lagerlöf's work is emphasized depends, of course, on the position of the writer on the scale between progressive and conservative. According to Lindholm Narváez, the most notable progressive periodicals were Heraldo de Madrid, Nuevo Mundo, and La Esfera, along with cultural journals such as La España moderna, challenging conservative ideals and promoting a modern, middle-class lifestyle (Lindholm Narváez 2013, 201-202). La Lectura, where Julian Juderias published his long introduction to Lagerlöf, was also a liberal journal. However, the profile of the journal was not decisive in how Lagerlöf was introduced: both Guerra and Juderias wrote in liberal journals with a progressive profile, but Guerra's image of Lagerlöf places more weight on the traditionalist aspects of her work and her author persona than Juderias. Furthermore, they both stress her rootedness in a specific landscape and her belonging to a people whose culture and mentality is reflected in her writing.

Lagerlöf was clearly not a representative of modern Scandinavia in the same way that Ibsen and Key were. Although she was credited with creating a different prose aesthetic than the established realism, the critics mostly focus on her return to the past and her retelling of old tales. Lagerlöf was not modern in the sense of Ibsen's Nora. She was independent, but not controversial. Being an unmarried woman, she avoided any discussion about the incompatibility of the roles of wife and mother with those of writer and public person. According to Lindholm Narváez, another icon of Nordic femininity besides Ibsen's Nora was Wagner's Valkyrie. Wagner's opera became very popular, and the Valkyrie “was used

14 "En sus novelas vibra entera el alma popular escandinava, el alma sueca, heredera de los rudos vikings y de los berserks", "su obra es benéfica, porque ella ha tenido entera a servir, glorificar y educar al pueblo sueco". 
by progressive intellectuals as a Nordic ideal to be contrasted with the Spanish women as passive victims of traditional conventions" (Lindholm Narváez 2013, 205). References to Nordic mythology were not uncommon in the French reception of Nordic literature. In her book about Swedish feminism, French feminist and writer Louise Cruppi argued that Swedish women had participated in male activities (for example warfare) over the centuries and mentioned the Valkyrie as part of the popular imagination influencing the role of modern women (Cruppi 1912, 16-17). ${ }^{15}$ I have found no direct references to the image of the Valkyrie in the reception of Selma Lagerlöf until 1914, even though Juderias does speak about Scandinavia's "sturdy and terrible old gods" (Juderias 1910, 44). ${ }^{16}$ If the Valkyrie was utilized to explain the phenomenon of the modern Nordic, independent woman, like Ibsen's Nora ready to fight for her cause, that image may have seemed unfit to apply to Lagerlöf or her female characters, as both she as an author and her texts were perceived as more in line with traditional values and with simple and humble femininity.

In contrast to the image of Sweden as a leading industrial country in de Lazúrtegui's travelogue, the rural, untouched aspects of Sweden are most apparent in texts about Lagerlöf. Both Guerra and Juderias place Lagerlöf in a rural landscape. Juderias claims that the farm in the novel Jerusalem is a truthful description of her childhood home, despite the fact that it is placed in the wrong landscape. She is described as an excellent observer of rural life, which is seemingly simple, but violent, passionate, and primitive underneath (Juderias 1910, 45-46). The article about Lagerlöf in Por Esos Mundos refers to a biographical text by Lagerlöf which is not specified and not easy to identify. It describes the combination of practical work and artistic enjoyment she was brought up in: "Wheat was grown, but also jasmine. Linen was spun, but in the meantime folk songs were sung. We studied history and grammar, but we also played comedies and learned verses" (Por esos Mundos 1909, 29). ${ }^{17}$ In 1911, Guerra quotes the exact same passage in La España moderna (Guerra 1911, 121). In his opinion, this "peasant household" ("hogar campesino") is in fact the determining factor in the development of Lagerlöf's imagination (Guerra 1911, 120). Though the image of the North as a pioneering region in both women's emancipation and industrial development was well established at the time, Lagerlöf's texts invited readings of

15 Fournier discusses the Valkyrie in texts French travelogues and essays about Sweden more at length. Fournier 1989, 254-258.

16 "los viejos dioses fornidos y terribles".

17 "Se cultivaba el trigo, pero también el jazmín. Se hilaba lino, pero entre tanto se cantaban canciones populares. Se estudiaban la historia y la gramática, pero se representaban comedias y se aprendían versos." 
the North as a place where the past is preserved and rural society prevailed. The idea of the North as a pre-capitalist idyll was not only a German idea (Gentikow 1978), but a notion spread across Europe.

\section{Conclusion}

In researching literary reception in different nations and language areas, cultural specificity is a necessarily important aspect. There are major differences between Lagerlöf's reception in Spain and in France, because France was a more culturally influential nation and Paris, according to Pascale Casanova, the capital of the world republic of letters (Casanova 2004, 83-91). Although a colonial power, Spain in the late 19th and early 20th centuries could not compete with the cultural centrality of France. This is obvious not least in the generous sections of Spanish cultural journals reporting what was written in French journals, including translations and reviews of foreign literature. Clearly a significant part of Lagerlöf's 1909-1914 reception in Spain is based on recycled texts. Juderias refers to an unnamed German critic and quotes André Bellessort, Lagerlöf's French translator and an important cultural intermediary for her in France. The article about Lagerlöf in La España moderna also refers to Bellessort's words in Revue de deux mondes that one must understand the Swedish nature to understand Lagerlöf's writing (La España moderna 1910, 200). As mentioned, two articles quote the same text by Lagerlöf as a biographical source concerning her childhood. While the French reception seems to have been influenced by direct contacts with Sweden, since several of those who wrote about her had travelled to Sweden (Jacques de Coussange, Léonie Bernardini-Sjöstedt, André Bellessort, Marc Hélys) (Fournier 1989), the Spanish reception was mediated through previous receptions, not only in France, but also in Germany. This may be one reason why the French - and by extension the Spanish reception - was in a sense so similar to the Swedish: both the national image of Selma Lagerlöf produced by Swedish critics and the image she herself promoted of her origin and her author identity were re-circulated.

Another explanation for this similarity is that Europe was a part of one literary system. Casanova argues that Paris, in the cultural meridian, was a place where writers from the periphery went to learn the diction of world literature and to abandon provincial or national writing. It might be tempting to contend that Casanova is proven wrong by Lagerlöf's case. Unlike Strindberg, and other modern Scandinavian writers who sought artistic freedom in Paris and used it as a literary laboratory (Briens 2010), Lagerlöf was not cosmopolitan and could not 
claim access to the Parisian universality Casanova formulates. ${ }^{18}$ However, the determining factor in her case was the Nobel Prize. It automatically included her in the world of European letters, even though she was not regarded as a modern, cosmopolitan writer, but as a provincial, national writer from the periphery. She came to embody the image of "woman" as a refuge from modernity, placed in a "sphere of atemporal authenticity seemingly untouched by the alienation and fragmentation of modern life" (Felski 1995, 16). This was a successful position for Lagerlöf. It allowed her to be a pioneering female author without being seen as a figure of threatening emancipation, and her traditional provincialism could be interpreted not as backwards, but as fulfilling a nostalgic longing for the authentic.

Not only did literature travel in Europe, ideas and ideologies did as well. As Gentikow has shown, the German image of the North exploited an idea of Scandinavia as an idyllic, rural region, untouched by modernity, and Ljung Svensson identifies the same tendency in the early reception of Lagerlöf in Germany. In this discourse, as in German romanticism, the landscape and the people were deeply connected. The conceptualization of the North in the reception of Selma Lagerlöf in Spain had many similarities to that in Germany. The expressions "rincón nativo" and "terruño natal”, frequently used to position Lagerlöf's prose in Spain, were also central concepts in the German Heimatkunst. As in Germany, place of origin was connected to character. While there are direct traces of the French critical reception in the Spanish, there is also a more general ideological and scientific discourse valid in Spain and in both France and Germany. Within the biologistic discourse on national character, taken to its racial extreme in the first half of the 20th century, not only is Lagerlöf interpreted as a portrayer of the nature of the people of the North, but her heritage and origins are also important elements in discussions of the author herself. Her origin in a specific birthplace (Värmland) is thus more significant than the nation, Sweden, and the region, Scandinavia, as the birthplace of the people or race.

Selma Lagerlöf came to personify the authenticity and anti-modernity of the northern Utopia through her portrayals of the landscape, the wilderness, and the life of farmers on ancient lands and inherited farms in Gösta Berling’s Saga and

18 I agree with the critiques articulated by Briens and Hanneken, from the points of view of Scandinavia and Latin America respectively, that Casanova's construction of Paris as the independent centre of literary Europe neglects the possibility of other centres not revolving around Paris (Hanneken 2010, 129-133) and that Paris was a transnational (but not an un-nationalized) cosmopolitan space, depending on the logics of different nationalities (Briens 2010, 80). At the time of Lagerlöf's Nobel Prize, all her books published in Swedish were translated into Russian and all but a collection of short stories into German. For Nordic literature, Russia and Germany were very important places for literary transfer. See Afzelius 1938. 
Jerusalem, and a bird's-eye view of Sweden in its entirety in The Wonderful Adventures of Nils. In the critic's view, her anthropomorphism and elements of folklore underlined the connection between people and nature, but also connected it to the past (e.g., traditions, old legends). In this sense, Lagerlöf represented something different from the "modern Scandinavia" represented most prominently by Ibsen in literature, by women's emancipation in society, and by the industrial advances observed by Spanish travellers such as de Lazúrtegui and de Burgos. Elements of what Stadius calls the progressive image appear in comments on Lagerlöf as a pioneering female author, but the traditionalist image dominates, possibly with elements of a chauvinist and Pan-Latinist image. The crucial different between the two main views is that the traditionalist includes a paternalistic and superior view of the people of the North, who are objectified and exoticized (Stadius 2005, 206). Guerra's articles show tendencies in this direction to include race and a cultural hierarchy that might be influenced by this kind of political discourse. However, it is difficult to separate this discourse from a popularized and touristic Spanish view on the North.

Finally, returning to the initial example of Concha Espina's admiration of Lagerlöf. The press material studied here provides no clues as to whether Espina's publicly displayed admiration of Lagerlöf was anything more than a strategic attempt to advance herself as a candidate for the Nobel Prize. However, an article from 1931 points to an aesthetic affinity between the two writers. Like Lagerlöf, Concha Espina can speak to the souls of the children and reach the child in all of us (Assens 1931, 6). Merely because Concha Espina admired Lagerlöf does not mean that she was generally popular in conservative, nationalist circles. In France, many of her most enthusiastic introducers were conservative (Bellessort was active in L'Action Française, de Coussange wrote the book Le Nationalisme Scandinave), but in Spain interest in Lagerlöf was mainly reflected in progressive journals. European nationalism, and later fascism, was often linked to race (most notably in Germany), but in Spain it was first and foremost a question of religion and conservatism (Lindholm Narváez 2013, 204-205). Although Espina came to support Franco, her embrace of Lagerlöf cannot be taken to indicate that Lagerlöf was understood to support conservative and nationalist ideals. She was apparently attractive to both Catholic, nationalist conservatives and progressive, cosmopolitan intellectuals.

This investigation of the reception of Selma Lagerlöf in Spanish press and periodicals has been an attempt to escape the binary distinction between centre and periphery, which locks the periphery in the position of satellite to the centre and the role of receiver of the centre's culture. However, a genuine dialogue between the two semi-peripheries of Spain and Scandinavia is difficult to discern, since the reception of Lagerlöf in Spain was mediated through previous critical statements 
originating from France, but also in Germany and Sweden. The Spanish image of the North in this material consequently has traits in common with the French, and also more generally with the British and German. The North, as a mental geography in the early 20th century, was clearly a transnational European product.

\section{Literature}

\section{Primary literature}

Anonymous 1906: "El movimiento literaria en Escandinavia”. In: Nuestro tiempo. 25 December. 539-542.

Anonymous 1909: “Los agraciados con los Premios Nobel en 1909." In: La llustración Artística. 27 December. 847.

Anonymous 1910: “Literatura extranjera. El Premio Nobel de Literatura”. In: Por Esos Mundo. 1 January. 29.

Anonymous 1910: “La labor de Selma Lagerlöf”. Revista de revistas. In: La España moderna. 5.22. 200-201.

Anonymous 1910: “Los Premios Nobel.” In: La Hormiga de Oro. 1 January. 19.

Anonymous 1913: "La literata que ha entusiasmado á un pueblo. Selma Lagerlof y su obras." In: Alrededor del Mundo. 26 February. 7.

Anonymous 1914: "Selma Lagerlof.” In: La llustración Artística. 15 June. 406.

Anonymous (signed “A Reader”) 1914: “Dos victorias feministas.” In: La Esfera. 27 June. [5].

Assens R. Cansinos 1931: "El niño en la literatura - una frase feliz de Antoniorrobles - Maestros y poetas." In: La Libertad. 19 March. 6.

De Burgos, Carmen 1915: Mis Viajes por Europa. Suiza, Dinamarca, Suecia, Noruega. Madrid. Cruppi, Louise 1912: Femmes Écrivains d'Aujourd'hui. I. Suède. Paris.

Espina, Concha 1925: De Dödas Metall. Translated by Reigin Fridholm. Stockholm.

Guerra, Ángel 1910: “Las escritoras modernas. Selma Lagerlöf.” In: La llustración Artística. 7 February. 91-92.

Guerra, Ángel 1911: “Literatura contemporanea. Selma Lagerlöf (Suecia).” In: La España Moderna 23.265. 117-137.

Juderias, Julian 1910: “El triunfo de la imaginación. Selma Lagerlöf.” In: La Lectura 10.1. 43-52. de Lazúrtegui, Julio (signed J de L) 1898: "Una excursión minera a la península escandinava.

De Bilbao a Gellivara.” In: España. 28 August. 2-3.

L'đEuvre de Concha Espina a l'étranger. Éditions polyglottes 1925. Madrid.

Remusat, Martine 1907: “El misticismo en la literatura escandinava." In: La Lectura 7.77. 338-344. Originally published in La Revue, December 1905.

\section{Secondary literature}

Afzelius, Nils 1938: "Selma Lagerlöfs världsrykte. En bibliografisk översikt över hennes översatta verk.” In: Nordisk familjeboks årskrönika.

Bergenmar, Jenny 2017: "Gender and Nationality in the French Reception of Selma Lagerlöf 1899-1912.” In: Herrero López, Isis, Cecilia Alvstad, Johanna Akujärvi and Synnöve 
Lindtner (Eds.): Gender and Translation. Understanding Agents in Transnational

Reception. Quebec. 127-149.

Briens, Sylvain 2010: Paris. Laboratoire de la Literature Scandinave Moderne 1880-1905. Paris.

Casanova, Pascale 2004: The World Republic of Letters. Translated by M. B. DeBevoise.

Cambridge, Mass./London.

D'Haen, Theo 2012: The Routledge Concise History of World Literature. London/New York.

Felski, Rita 1995: The Gender of Modernity. Cambridge, Mass.

Fjågesund, Peter/Ruth A. Symes 2003: The Northern Utopia. British Perceptions of Norway in the Nineteenth Century. Amsterdam/New York.

Fjågesund, Peter 2014: The Dream of the North. A Cultural History. Amsterdam/New York.

Fournier, Vincent 1989: L'utopie Ambiguë. La Suède et la Norvège chez les Voyageurs et Essayistes Français (1882-1914). Clermont-Ferrand.

Gentikow, Barbara 1978: Skandinavien als präkapitalistische Idylle. Rezeption gesellschaftskritischer Literatur in deutschen Zeitschriften 1870-1914. Neumünster.

Hanneken, Jaime 2010: “Going mundial. What it really means to desire Paris.” In: Modern Language Quarterly 71.2.129-152.

Leersen, Joep 2000: "The rhetoric of national character. A programmatic survey." In: Poetics Today 21.2. 267-292.

Leersen, Joep 2007: “Imagology. history and method.” In: Imagology. The Cultural Construction and Literary Representation of National Characters. Amsterdam. 17-32.

Lindholm Narváez, Elena 2015: "La modernidad de otra parte. La mirada de Carmen de Burgos sobre Escandinavia." In: Cuesta, Lorena Saletti (Ed.): Translaciones en los estudios feministas. Málaga. 182-207.

Lindholm Narváez, Elena 2013: "The Valkyrie in a bikini. The Nordic woman as a progressive media icon.” In: Harvard, Jonas and Peter Stadius (Eds.): Communicating the North. Media Structures and Images in the Making of the Nordic Region. Farnham. 197-218.

Ljung Svensson, Ann-Sofi 2011: Jordens dotter. Selma Lagerlöf och den tyska hembygdslitteraturen. Göteborg/Stockholm.

Mignolo, Walter 2002: “Rethinking the colonial model.” In: Hutcheon, Linda and Mario J. Valdés (Eds.): Rethinking Literary History: A Dialogue on Theory. Oxford/New York. 155-193.

Rideout, Judith 2016: Women's Writing Networks in Spanish Magazines Around 1900. Glasgow.

Rogers, P. P. and F. A. Lapuente 1989: Diccionario de seudónimos literarios Españoles, con algunas iniciales. Barcelona.

Siguan, Marisa 2001: “Northern role models and the 'drama of ideas'.” In: Martínez Ruiz, Enrique and Magdalena de Pazzis Pi Corrales (Eds.): When the Light Came from the North. Sweden, Norway and Modernist Catalunya. Barcelona. 25-45.

Stadius, Peter 2005: Resan till norr. Spanska Nordenbilder kring sekelskiftet 1900. Helsingfors. Thorup Thomsen, Bjarne 2014: “Re-Mapping Lagerlöf. This volume and its parameters." In:

Forsås-Scott, Helena et al. (Eds.): Re-mapping Lagerlöf. Performance, Intermediality, and European Transmissions. Lund, 13-17.

Ugarte, Michael 1997: “The Fascist Narrative of Concha Espina”. In: Arizona Journal of Hispanic Cultural Studies 1.1. 97-114.

Watson, Jennifer 2014: "Selma Lagerlöf in Nazi Germany. Not banned, not forgotten: Lord Arne's silver as a Nazi frontbuch.” In: Forsås-Scott, Helena et al. (Eds.): Re-mapping Lagerlöf. Performance, Intermediality, and European Transmissions. Lund. 302-314. Youngs, Tim 2013: The Cambridge Introduction to Travel Writing. Cambridge. 